\title{
Proteasome Subunit Beta Type-9
}

National Cancer Institute

\section{Source}

National Cancer Institute. Proteasome Subunit Beta Type-9. NCI Thesaurus. Code C73448.

Proteasome subunit beta type-9 $(219 \mathrm{aa}, \sim 23 \mathrm{kDa})$ is encoded by the human PSMB9 gene. This protein is involved in the proteolytic processing of antigenic proteins into peptides that bind to major histocompatibility complex class I proteins. 